\title{
Improving Community Performance by Re-examining the Neighborhood ${ }^{1}$
}

Randall A. Cantrell ${ }^{2}$

\section{Quick Facts}

- The negative effects noise has on citizens' feelings of well-being in the community are a well-known concern (U.S. EPA, 1977).

- Crime-watch systems in $83 \%$ of neighborhoods studied showed a favorable effect on crime (Bennett, Holloway, \& Farrington, 2006).

\section{Terms to Help You Get Started}

Community: The neighborhoods, public schools, and public services found in a specific area

Overall community performance: How well the neighborhoods, public schools, and public services address citizens' needs and desires

Recreation: Measures taken to provide convenience to a community's citizens

Ordinance: A law passed by a municipal government

Security: Measures taken to help citizens feel safe in their community

\section{Keywords}

Community performance, citizen behaviors, neighbor-

hoods, public schools, public service

\section{Introduction}

This series of EDIS publications introduces readers to the concept of overall community performance and suggests minor modifications to neighborhoods, public schools, and public services that could help citizens improve their communities. This publication is for a general audience and provides a list of considerations for changes to neighborhoods that, if enacted, may help improve a community's performance. The other three publications in this series include the following:

- Improving Community Performance by Re-examining Public Schools (http://edis.ifas.ufl.edu/fy1374)

- Improving Community Performance by Re-examining Public Services (http://edis.ifas.ufl.edu/fy1373)

- Improving Savings, Health, and Happiness by Making Small Modifications to Your Community (for an academic audience) (http://edis.ifas.ufl.edu/fy1371)

1. This document is FCS3315, one of a series of the Department of Family, Youth and Community Sciences, Florida Cooperative Extension Service, Institute of Food and Agricultural Sciences, University of Florida. First published May 2013. Please visit the EDIS website at http://edis.ifas.ufl.edu.

2. Randall A. Cantrell, assistant professor, Department of Family, Youth and Community Sciences; Florida Cooperative Extension Service, Institute of Food and Agricultural Sciences, University of Florida, Gainesville, FL 32611.

This material was prepared with the support of the University of Florida. However, any opinions, findings, conclusions, or recommendations expressed are those of the author(s) and do not necessarily reflect the views of the University of Florida. 


\section{The Realities of Privacy in a Neighborhood}

A family recently moved into a nice home in a neighborhood so that they could be closer to extended family and desirable jobs. The neighborhood had a homeowners' association. Residents had to pay dues and follow the association's covenants as well as city ordinances. The family wanted to meet their new neighbors, so the father took his daughter next door. Their neighbors told them that people from the neighborhood were gathering for a get-together later that night. The father and daughter wished everyone well, and explained to the neighbors that they needed to return home to join the mother and newborn baby.

The neighbors then proceeded to have a noisy outdoor gathering until the early hours of the morning. The new homeowner woke up on several occasions because of the gathering, but he did not feel comfortable confronting people he didn't know well and who were possibly drinking alcohol. The new homeowner faced the decision of lying awake in bed and risking the baby being woken up, or contacting the authorities. He decided to contact the authorities (on this occasion and several others), until all was resolved. However, when he contacted the president of the neighborhood homeowners' association to explain the events, the president said the association had no rules governing noise. The new homeowner nearly panicked when he learned that all-night, outdoor gatherings were acceptable in the neighborhood. Fortunately, the family and their neighbors eventually reached an amicable solution through extended communication, common sense, and good fortune.

This story presents one example of how a neighborhood's policies and ordinances can affect a family and the community's well-being. Enacting and enforcing neighborhood policies and ordinances that everyone can agree with can help to improve overall community performance.

\section{How Might Your Family Benefit by Improving Overall Community Performance?}

The concept of overall community performance has much to do with re-thinking how people can be happier, which is not necessarily the same as being comfortable. Finding ways to keep people living next to each other in the same neighborhood and in a relatively peaceful state is not an easy task. But reaching agreements rather than spending time and money resolving disputes is an attainable goal and one worthy of pursuit. If families focus on the various factors comprising overall community performance, they may be able to save time and money while also strengthening the neighborhood and community. However, improving the community sometimes takes place in small increments and often requires time before results are noticeable.

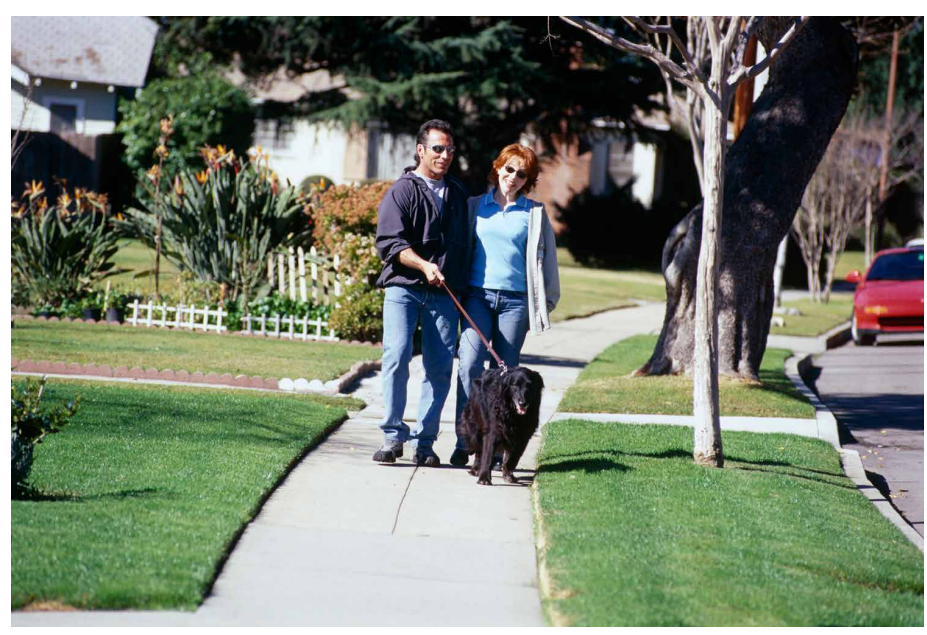

Figure 1. Neighborhood policies and ordinances can affect the well-being of individuals in the community and overall community performance.

Credits: Creatas

\section{How Are Neighborhood Practices Chosen to Improve Overall Community Performance?}

Respondents from a representative sample in the United States were asked to rate multiple items-as identified in the literature-that could improve overall community performance (Cantrell \& Stafford, 2013). The goal was to determine which of 81 items the respondents thought had the greatest likelihood of improving their community's overall performance. In the neighborhood practices category, participants chose 22 of 27 modifications.

\section{Neighborhood Modifications That Most Impact Community Improvement}

List 1 shows the neighborhood modifications sample participants felt could most likely improve overall community performance. These modifications mostly reflect better enforcement of community ordinances. 


\section{List 1. Neighborhood Modifications That Most Impact Overall Community}

\section{Improvement}

- More stringent, enforceable noise ordinances. These may encourage residents to respect their neighbors' privacy, especially during nighttime hours when most people are sleeping.

- More enforceable vehicle noise ordinances. Such ordinances may discourage neighbors from supplementing their vehicles with accessories that create loud noises (i.e., deep-bass stereos, exhaust pipes, etc.).

- More enforceable ordinances on the number of vehicles that can be parked in a residential lot. These rules can discourage neighbors from storing more vehicles and accessories on their property than they can use on a routine basis.

- More enforceable animal policing ordinances. Such regulations may require pet owners to be responsible for where they allow their animals to eliminate.

- More enforceable animal leash ordinances. These may allow residents to move freely in their neighborhood with less concern for personal safety.

- Security cameras installed in undisclosed locations throughout neighborhoods. Cameras may provide assurance that other residents are abiding by the ordinances and covenants and that no suspicious activity or strangers are in the neighborhood.

- More stringent neighborhood crime-watch initiatives. These initiatives may help neighbors know everyone is looking out for everyone else and no suspicious activity or stranger will go unnoticed or unreported.

\section{Neighborhood Modifications That Marginally Impact Community Improvement}

List 2 shows neighborhood modifications sample participants felt could marginally improve overall community performance. These modifications did not align with any specific theme.

\section{List 2. Neighborhood Modifications That Could Marginally Improve Overall Community Performance}

- Having gated entrances to neighborhoods

- More enforceable grass length/lawn mowing ordinances
- More stringent homeowner associations/more enforceable covenants and deed restrictions

- Restrictions that only allow traditional stick-built construction (no alternative housing)

- Having homeowner associations use private companies to observe conditions of homes in neighborhoods

- Having websites for homeowner associations

- Not allowing rental properties in the same subdivisions as homeowner properties

- More speed humps/bumps

- More enforceable speed limits

- More speed limit signs

- More portable speed-indicator radar units

- More sidewalks

- More streetlights

- Having walking/running/bicycle paths

- More public recreation areas

\section{Summary}

Making minor modifications to your neighborhood will not result in instant improvements to the overall performance of your community. However, if you make minor changes to your neighborhood along with other communityperformance measures (e.g., modifications to public schools and public services), the overall performance of your community may improve over time. The point is not to seek instant results but rather to establish practices to help citizens with as many of their needs and desires as possible.

\section{References}

Bennett, T., Holloway, K., \& Farrington, D.P. (2006). Does neighborhood watch reduce crime? A systematic review and meta-analysis. Journal of Experimental Criminology 2(4), 437-458.

Cantrell, R., \& Stafford, A. (2013). The introduction and development of the community-flow measurement instrument. Journal of Community Development. doi:10.1080/155 75330.2012 .761640

U.S. Environmental Protection Agency, Office of Noise Abatement and Control. (1977). The urban noise survey. Washington, DC: U.S. EPA. 